case of simple glaucoma) answers more closely to the contraction of the ciliary muscle than to the stricture of the pupil, it is not unnatural to attribute a pressure-diminishing effect to the contraction of the ciliary muscle. Dr. Raeder's observation is not published yet, but he has allowed me to quote it, as it is of interest in this connection. The observation made by Professor Grönholm that with some persons the pressure is lower after reading may perhaps be interpreted in the same direction.

\title{
PRINCIPAL REFERENCES
}

Berner, O.- " Relation entre le muscle dilatateur, etc." Comp. rend. Assoc. des Anat., 1925.

Holth and Berner.-"Congenital Miosis, etc," Brit. Jl. of Ophthal., 1923.

Idem. - "Miosis congenita, etc." Videnskapsselskapets Skrifter I, MatNaturv., Klasse, 1922.

Idem. - "Another case of congenital miosis, etc." Videnskapsselskapets Skrifter I, Mat-Naturv., Klasse, 1924.

Forsmark.- " Zur Kenntnis der Irismuskulatur." Mitteilungen aus der Augenklinik d. Carol. medico-chirurg., Inst. Stockholm, 1905,

Grunert.-“Der Dilatator pupillae." Arch. f. Augenheilk., 1898.

Grynfellt. - "Le muscle dilatateur." 1899.

Grönholm. - "Nogra anmärkningar til läran om glaucom." Finska Läkarasälskapets, Handlingar, 1911.

Heerfordt. - "Studien über den Musculus dilatator." Anatom., Hefte, 1900.

Mawas. - " Sur la forme, la direction et le mode d'action du muscle ciliaire." Compt. rend. des Sciences, 1912.

Idem. - "Du rôle du tissue conjonctif du corps ciliaire dans la transmission du muscle ciliaire," Compt. rend. des Sciences, 1913.

Idem.- " Sur un nouveau procédé de décoloration des coupes histologiques." Compt. rend. Soc. Biol., 1913.

v. Szily.- " Beiträge zur Kenntnis der Anatomie und Entwickelungsgeschichte der hinteren Irisschichten." Arch.f. Ophthal., 1902.

\section{NEW FORMED VESSELS IN THE VITREOUS OF SPECIFIC ORIGIN, WITH REPORT OF A CASE WITH DRAWINGS}

BY

\author{
C. A. Clapp, M.D., F.A.C.S.
}

FROM THE DEPARTMENT OF OPHTHALMOLOGY, JOHNS HOPKINS MEDICAL SCHOOL

NEw formed vessels developing in the vitreous have been described frequently in American ophthalmic literature, one of the earliest cases being described by $\mathrm{S}$. Theobald in 188\%, which occurred in a woman, aged 52 years, following a haemorrhage into the vitreous.

Marple in 1901 was fortunate in being able to study such a case ophthalmoscopically and later with the microscope, and again ophthalmoscopically in 1906, when another patient presented herself with vessels extending from the nerve-head $8 \mathrm{D}$. into the vitreous. Both of his cases were in women, the first being 50 years of age and the other 63 . 
Harlan in 1889 reported a woman, aged 50 years, with vessels extending $4 \mathrm{D}$. from the nerve in a large mass, being veil-like in appearance.

Davis in 1912 and Jackson in 1916 reported new formed vessels in young adults of tuberculous origin, and Bell in 1922 one caused by Hodgkin's Disease.

The case I wish to report was an adult male, aged 33 years, occupation, sea captain. His family history and past history

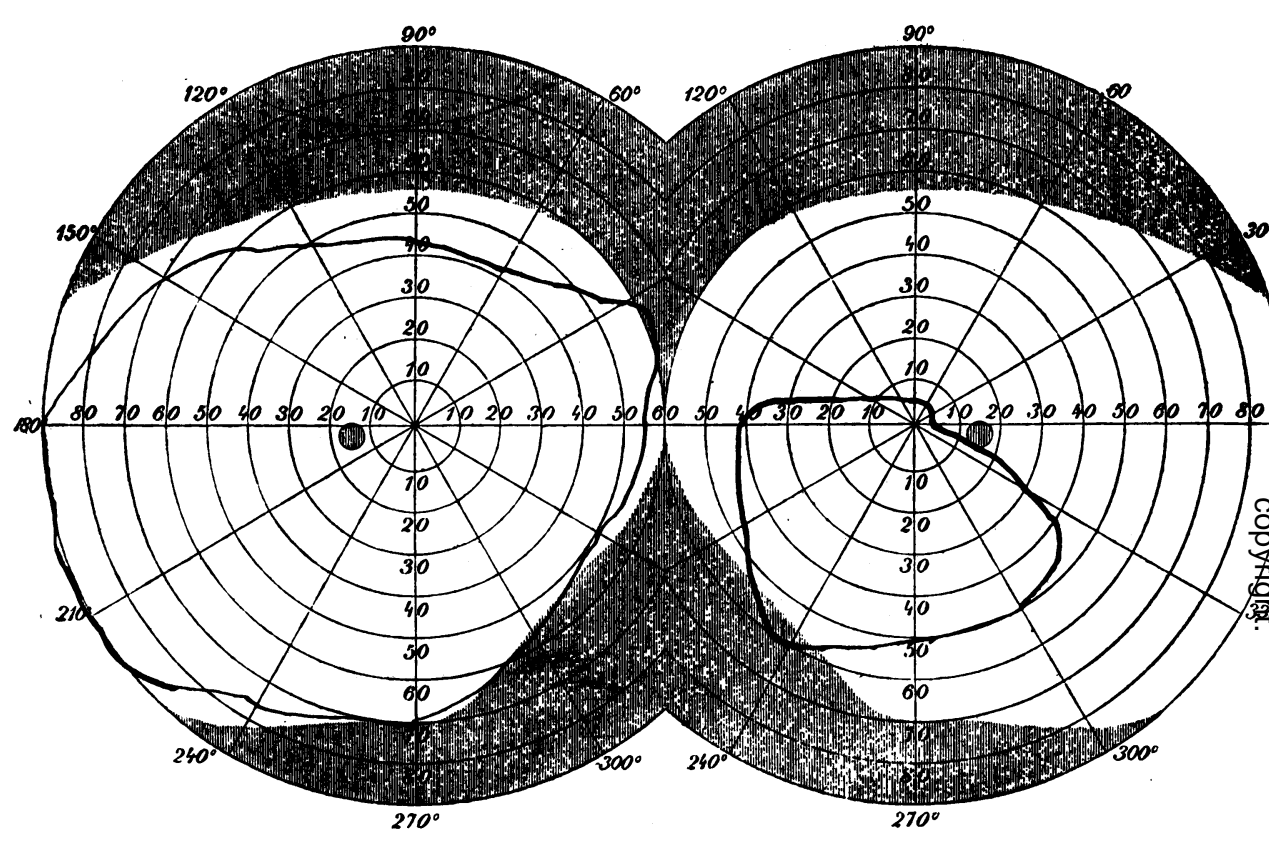

FIG. 1.

Fields of Vision.

were unimportant except his frequent exposure to venereal infection and at one time receiving anti-luetic treatment for a short time and later being told that he never had a lesion. His present history given on January 15, 1920, was that in October, 1919, he had suffered with a severe headache with troublesome spots before each eye and in December, 1919, he noticed that the vision in the left eye was poor and on January 1, 1920, the vision in the right eye was failing. By the use of the eyes of his first mate he was able to make port. On January 15, 1920, the examination showed vision reduced to $15 / 200$ in each eye. The external examination was negative although the pupils were slightly dilated ; they reacted both to light and accommodation. Ophthaimoscopically, the right eye showed vitreous slightly cloudy, out- 
lines of nerve entirely obliterated with slight elevation of centre of nerve; in and surrounding the nerve-head were numerous haemorrhages and exudates confined chiefly to the fibrous layer, and with extensive retinal oedema. In the lower part of the fundus there was a very large exudate extending out into the vitreous. The left eye showed practically the same changes as

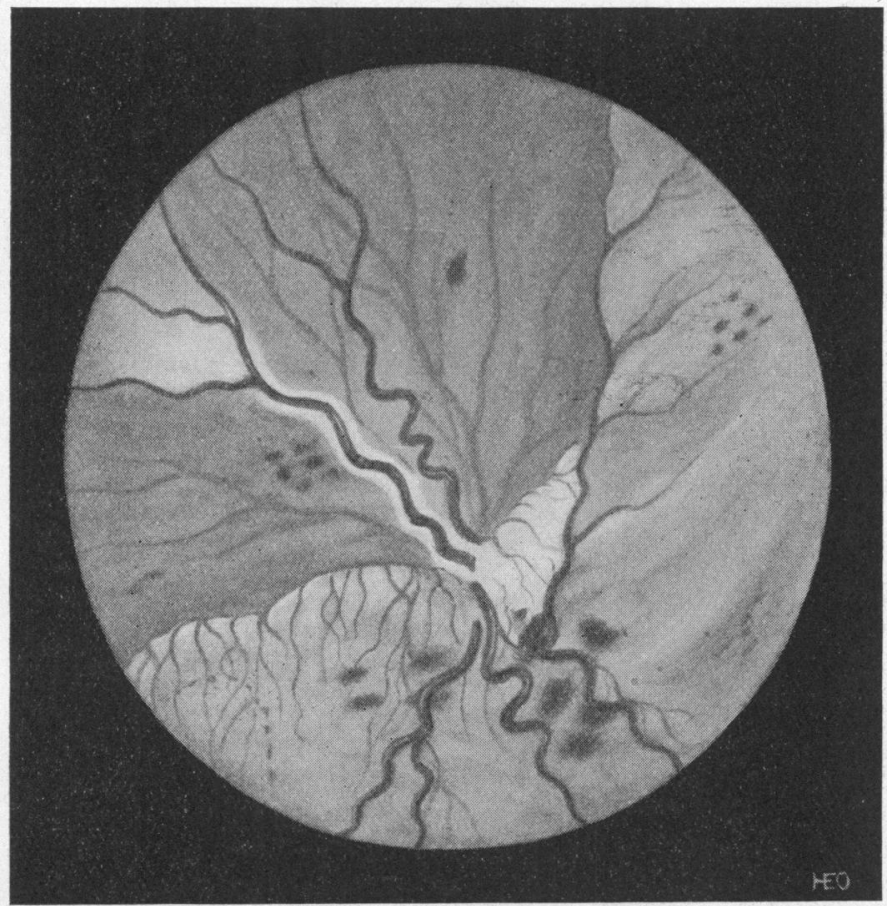

FIG. 2.

Drawing of Right Fundus, August, 1920.

the right with the exception that there was no large exudate in any portion which projected into the vitreous.

His physical examination showed slight enlargement of the tonsils and a markedly positive Wassermann. He was placed in the hospital and started on active anti-luetic treatment. In two months the outlines of each nerve could be made out and vision was 20/100 in each eye, but the right eye showed large haemorrhages below the nerve-head with new-formed vessels. One month later he showed more fresh haemorrhages in O.D., vision being 20/200 right and 20/50 left. Pronounced connective tissue was developing over the right nerve-head with some elevation of the retina. 
June 2, 1920. Large detachment of retina below in O.D., with new formed vessels coming out from left nerve-head.

June 18. His vision in O.D. was reduced to fingers at two feet, and with apparently the same condition developing in O.S.

A consultation was arranged with Dr. de Schweinitz who advised removal of tonsils, giving $20 \mathrm{gr}$. calcium lactate three

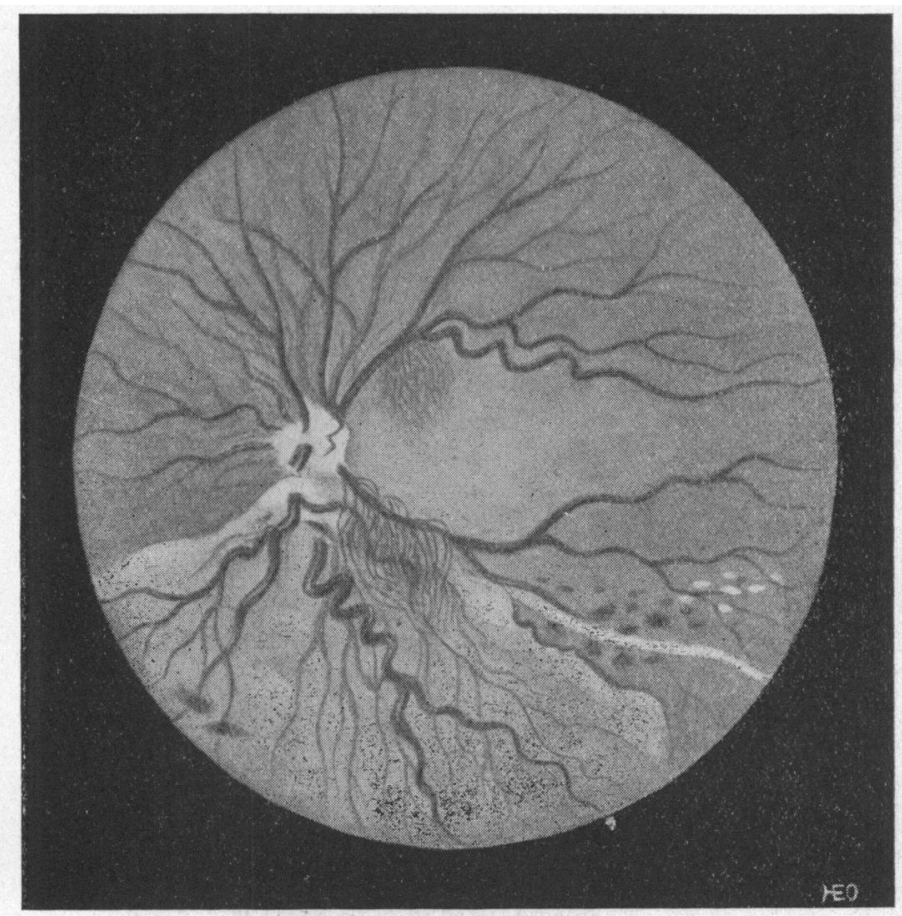

FIG. 3.

Drawing of Left Fundus, August, 1920.

times a day and pushing the iodides and mercury. The medical therapy was carried out but the patient refused the operation advised upon the tonsils.

July 1 . His vision in the left had improved to $20 / 30$ plus, and he passed the examination for captain's licence.

On August 17 his eyes presented the picture as seen in the plates. The right nerve was entirely obliterated by connective tissue and the detachment involved the entire nasal side and lower part of the fundus. There were haemorrhagres in both the attached and detached retina. Some fine vessels extended into the vitreous about the nerve-head which are not shown especially well in the drawing. The detachment retained considerable colour suggesting 
that possibly the choroid was also elevated. The left fundus was even more interesting as the leash of vessels coming out into the vitreous was better seen. These were countless in number and seemed to be closely associated with the large arteries and veins; as they came forward they diminished in size and seemed to end at a focus of eight dioptres. The free extremities seemed to lie in the vitreous and as the eye was moved they would float about with a very slow movement. There was much retinal oedema in the macular region and below the nerve both arteries and veins were very dark and tortuous and definitely elevated, being situated upon a much lighter background; a connective tissue band extended temporally, about which were haemorrhages and exudates. The ultimate outlook of this appeared very grave.

October 5. No apparent change in left fundus except that the haemorrhages were becoming smaller. The detachments in right have continued to increase. Patient had been taking increasing doses of potassium iodide.

November 3. Vision O.S. 20/30. Patient is taking $115 \mathrm{gr}$. of iodide three times daily.

November 16 . Is taking $129 \mathrm{gr}$. of iodide. Iodide discontinued and given biniodide of mercury.

May 31,1921 . Vision in O.S. with glass $(-1.75$ D. Sph. $)=20 / 20$.

July 23, 1921. O.D. still shows small area of fundal reflex high up. O.S. still shows new formed vessels in vitreous but haemorrhages are practically absorbed and Wassermann is negative.

January 3, 1922. O.D. still shows small area of fundal reflex up and out. Vision motion. O.S. no change in fundus. Vision $20 / 20$.

January 16, 1923. Vision O.D. motion. O.S. 20/16.

Right pupil bound down with posterior synechiae and lens becoming opaque: No part of fundus can be seen. Left nerve outline obliterated down and out by connective tissue from which small vessels extended $2 \mathrm{~mm}$. into the vitreous. A connective tissue band extends across the fundus horizontally; below the nerve-head at the temporal side there is another group of small vessels which extends forward 7D. No elevation of retina.

April 3, 1924. O.D. light perception; vision O.S. 20/20. Right lens entirely opaque. I.eft fundus shows practically same picture as that of January, 1924. The fields as shown are as one would expect with the location of the detachments.

The reviewer of the tenth edition of Dr. de Schweinitz's book "Diseases of the Eye," published in the ninth volume page 138 of the Brit. Jl. of Ophthal., apparently doubts the presence of these vessels in the vitreous, as he states "the illustration, Fig. 219, showing new formed vessels in the vitreous must 
be of very rare occurrence or else the picture is somewhat misleading."

While I think the condition is relatively very rare yet there is no doubt about its occurrence, and in this case it was undoubtedly the result of lues causing vitreous haemorrhages which were followed by these vascular changes. This condition seems to be quite different from the ordinary picture of new formed vessels as seen in retinitis proliferans, in the innumerable quantity of vessels, variously described as a veil or mass of vessels and in their apparent freedom of attachment except at their base.

Marple's case which came to section showed microscopically the optic nerve fibres extending directly from the papilla forwards into the vitreous. Among these fibres fine blood-vessels were found which were branches of the vessels on the nerve-head. The retina was not detached but connective tissue bands extended forwards and then lateraliy to the ora serrata.

The nerve fibres extended forwards about $3 \mathrm{~mm}$. in front of which there was a central stalk of new formed vessels supported by a delicate stroma of connective tissue; about $4 \mathrm{~mm}$. behind the lens it branched out and fibres extended to the ora serrata.

In several reported cases the vessels have entirely disappeared, especially if the aetiology were syphilis and treatment were inaugurated.

They apparently may result from vitreous haemorrhages or less frequently from any form of exudate, as one finds reports of syphilis, tuberculosis, diabetes, and Hodgkin's Disease as factors. But syphilis is responsible for about 50 per cent. of the cases.

The reason for the prolific formation of small vessels as shown gives ample room for speculation, but it would seem almost impossible of absolute determination. While Marple's case showed the nerve fibres extending forwards from the optic nerve, that certainly can hardly be the case in these cases which retain $20 / 20$ vision or those in which the vessels disappear.

While the danger resulting from detachment of the retina is very great as exemplified in the right eye of the reported case, the vessels in themselves do not obstruct vision as seen in the left eye which still retains $20 / 20$ vision.

Prognosis.-It would seem from this case history that while the prognosis should be guarded it is not necessarily bad.

Although the vision of the right eye was entirely destroyed and a very grave prognosis made of the left at the time of the extensive detachment and the formation of new vessels, the patient, in the left eye, retains after five years $20 / 20$ vision.

Treatment.-While active anti-luetic treatment is indicated if the case is specific, I am not so sure that the arsenical preparations are those of choice, as it seemed on two occasions that the intra- 
ocular haemorrhages were made worse after this treatment, and finally, the improvement seemed much more rapid under mercury and potassium iodide, and the latter was apparently quite a factor in inducing the absorption of the exudate underlying the detachment, thus causing reattachment of the retina.

\section{ANNOTATION}

\section{The National Physical Laboratory}

The inspection by the Genera! Board took place this year on June 24. The programme of exhibits was fully up to the usual high standard. Those of our readers who were present at the Annual Congress of the Ophthalmological Society of the United Kingdom and availed themselves of the privilege of inspecting the laboratory on that occasion will need no reminder of the value and interest of the work carried on there. The accuracy obtainable by modern physical methods should make a special appeal to the ophthalmologist.

We were particularly impressed by the vector colorimeter. "The object of this instrument is to enable a colour to be specified by qualitative measurements involving colour matches only, so as to avoid difficulties inherent in the quantitative evaluation of the constituents of a colour match. Briefly, this is effected by locating the unknown colour on a colour chart by the intersection of two vectors. Two colour matches are made. In one the test colour is matched by a mixture of spectrum red with monochromatic light of suitable wave-length ; in the other by a mixture of spectrum blue with another suitable monochromatic constituent. These matches determine the two vectors. Having determined the position of the colour on the colour chart, its specification on any of the standard systems is obtainable."

A model was also shown of one of the new rooms in the Duveen wing of the Tate Gallery, which has been constructed to a special design with the object of reducing the effect of reflections in the glazing of pictures. The necessary experiments were carried out at Teddington. This room has recently been opened br H.M. the King, and the method of illumination appears by general consent to be extremely successful.

In the photometry division a hollow sphere ten feet in diameter to be used for measuring the efficiency of fittings used for interior lighting, street lighting, and similar purposes was exhibited. It is believed to be the largest sphere in the world used for this purpose. In the same division was also shown a room lighted through a window covered by translucent paper by an artificial 